\title{
UPAYA PEMBENTUKAN KARAKTER PADA SISWA KELAS V MELALUI PENDIDIKAN KEAGAMAAN DI MI SALAFIYAH 02 TASIKMADU TAHUN \\ PELAJARAN 2017/2018
}

\author{
Oleh: Taufik, Siti Nurjanah* \\ Sitinurjanah@stitmatuban.ac.id
}

\begin{abstract}
ABSTRAK
Religious education is expected to be able to produce good personality traits. A good child personality can be seen with his efforts in perfecting faith, piety, and noble character. Such noble character includes ethics, character, or morals as an embodiment of education.

Based on the background of the problem, this research is expected to provide an answer to the problem formulation (1) What is the effort of character building in fifth grade children through religious education at MI Salafiyah 02 Tasikmadu? (2) How is the effectiveness of character building in grade $\mathrm{V}$ children through religious education at MI Salafiyah 02 Tasikmadu? (3) What are the inhibiting and supporting factors in character building in fifth grade children through religious education at Salafiyah 02 Tasikmadu MI ?.

This research was conducted at Salafiyah 02 Tasikmadu MI by using qualitative research. Qualitative research is a method for understanding individuals that is done integratively and comprehensively in order to obtain a deep understanding of the individual and the problems he faces with the aim of the problem being solved and obtaining good selfdevelopment. The type of qualitative research used in this study is intended for children. In addition, the qualitative research approach is expected to reveal the situation and problems faced in the effort to shape character through religious education.

The results of the research are the efforts carried out by researchers in this research are to shape the character of children through religious education by inviting children to carry out religious activities. For example prayers together, istighosah do'a before and after learning etc. These are all part of the efforts made by researchers to familiarize children with awareness to carry out religious activities. The effectiveness of religious education in forming characters in Salafiyah MI began to appear. Children who were initially lazy to carry out religious education activities are now starting to be active along with the formation of character that is carried out regularly every day. Religious education is very effective in shaping the character of a child that begins to fade with the times. With this study held, in Salafiyah MI 02 the Tasikmadu began to appear that character emerged with various religious education activities. The inhibiting factor of this research is that the area is not extensive, because the children are still alternating with other classes, lack of enthusiasm of children towards religious activities, besides that there are still children who like to joke when the activities take place. Supporting factors in forming educational activities are teachers at Salafiyah MI 02 Tasikmadu always follows the activities carried out, children who are starting to be enthusiastic about religious education activities always start when the activity takes place.
\end{abstract}

Key words: Character Building, Religious Education

* Siti Nurjanah adalah Kaprodi PGMI dan Dosen PGMI Sekolah Tinggi Ilmu Tarbiyah

Makhdum Ibrahim. Taufik adalah Mahasiswa Sekolah Tinggi Ilmu Tarbiyah Makhdum

Ibrahim 


\section{A. PENDAhULUAN}

Karakter merupakan hal yang tidak lepas dari diri manusia, khususnya pada anakanak usia sekolah. Pendidikan karakter harus dimulai sejak dini, karena apabila anak anak tidak dibekali oleh pendidikan karakter bangsa ini akan rusak. Sekolah bukan hanya tempat menimba ilmu, tetapi juga sebagai tempat berkumpul, bermain dan berbagai keceriaan antara siswa yang satu dengan siswa yang lainnya sehingga terjadi interaksi di dalamnya. Sekolah juga merupakan tempat dimana kegiatan belajar mengajar berlangsung dan tempat terjadinya interaksi antara guru dan murid.

Dalam pembentukan karakter diperlukan cara supaya pendidikan karakter itu dapat diterima oleh siswa. Melalui pendidikan agama diharapkan mampu untuk mengahasilakan karakter kepribadian anak yang baik. Kepribadian anak yang baik tersebut dapat terlihat dengan upayanya dalam menyempurnakan iman, takwa, dan berakhlak mulia. Akhlak mulia tersebut antara lain mencakup etika, budi pekerti, atau moral sebagi perwujudan dari pendidikan. Didalam Al-Qur'an di jelaskan dalam Surat Al-Ahzab ayat:21

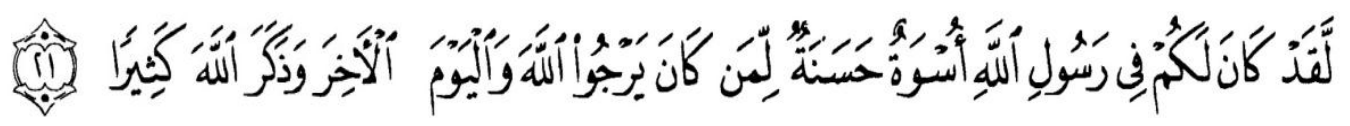

Artinya: Sesungguhnya telah ada pada (diri) Rasulullah itu suri tauladan yang baik bagimu yaitu bagi orang-orang yang berharap (Rahmat) Allah dan (kedatangan) hari kiamat dan dia banyak menyebut Allah (QS. Al Ahzab:21)

Anak yang memiliki karakter kepribadian yang baik dan luhur diharapkan tangguh dalam menghadapi tantangan, hambatan dan perubahan yang muncul dalam perkembangan di era globalisasi ini. Pendidikan agama merupakan pondasi dari anak untuk pembentukan karakter. Apabila hanya karakter saja yang di kembangkan maka akan sia-sia. Dengan perkembangan zaman yang modern ini, banyak anak yang meninggalkan pendidikan keagamaan, maka dari situlah perlunya pendidikan ahlaq yang baik bagi anakanak melalui pendidikan keagamaan pada siswa. Dalam sebuah Hadist Rasulullah bersabda :

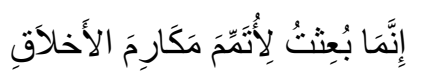

Artinya: "Sesungguhnya aku diutus untuk menyempurnakan akhlaq yang mulia" (Dishahihkan oleh Al-Albani dalam As-Shahihnya No.45)

MI Salafiyah 02 adalah madrasah satu - satunya yang ada di desa Tasikmadu yang memiliki potensi anak didik yang berkualitas. Selain ilmu pengetahuan anak juga akan 
mendapatkan ilmu agama yang mendalam. Contohnya ilmu fiqih, akidah akhlak, sejarah kebudayaan islam (SKI), Al-qur'an hadits, bahasa arab maupun aswaja. Anak didik akan memperoleh semua ilmu itu dengan sempurna apabila diikuti dengan pembentukan karakter yang dimulai dari kecil sampai nanti dia keluar dari madrasah melalui pendidikan agama.

Oleh karena itu, maka penulis merasa termotivasi untuk melakukan penelitian untuk Ppeserta didik yang berada di sekolah dengan mengambil judul "Upaya Pembentukan Karakter Pada Siswa Kelas V Melalui Pendidikan Keagamaan Di Mi Salafiyah 02 Tasikmadu Tahun Pelajaran 2017/2018”

\section{B. KAJIAN TEORI}

\section{a. Pengertian pembentukan}

Pembentukan menurut KBBI berasal dari kata " bentuk" berubah menjadi pembentukan [pem·ben·tuk·an] yang artinya proses, cara, perbuatan membentuk. Pembentukan memiliki 1 arti. Pembentukan berasal dari kata dasar bentuk. Pembentukan memiliki arti dalam kelas nomina atau kata benda sehingga pembentukan dapat menyatakan nama dari seseorang, tempat, atau semua benda dan segala yang dibendakan (KBBI, $1990: 200$ ).

\section{b. Pengertian Karakter}

Kata karakter secara etimologis seperti termuat dalam Kamus Besar Bahasa Indonesia karakter diartikan sebagai sifat-sifat kejiwaan, akhlak atau budi pekerti yang membedakan seseorang dari yang lain (KBBI, 2008: 258). Sedangkan dalam kamus umum bahasa Indonesia kata karakter berarti tabiat, watak, sifat-sifat kejiwaan, akhlak atau budi pekerti yang membedakan seseorang dengan orang lain (W.J.S. Poerwodarminta, 2006:521).

Pengertian karakter secara etimologis menurut para ahli adalah sebagaimana diuraikan berikut ini. Syarbini menyatakan kata karakter berasal dari bahasa Inggris, karakter (character) yang berarti a distinctive differentiating mark, tanda atau sifat yang membeda-kan seseorang dengan orang lain (Amirulloh Syarbini, 2012:13).

Menurut Marzuki karakter merupakan nilai-nilai perilaku manusia yang universal yang meliputi seluruh aktifitas manusia, baik dalam rangka berhubungan dengan Tuhannya, dengan dirinya, dengan sesama manusia, maupun dengan lingkungannya, yang terwujud dalam pikiran, sikap, perasaan, perkataan, dan 
perbuatan berdasarkan norma-norma agama, hukum, tata karma, budaya, dan adat istiadat (Marzuki, 2009:35).

Kesuma menyatakan bahwa karakter merupakan nilai tentang sesuatu. Suatu nilai yang diwujudkan dalam bentuk prilaku individu itulah yang disebut karakter yang melakat dengan nilai dari prilaku tersebut. Karenanya tidak ada prilaku yang tidak bebas dari nilai. Hanya sejauhmana kita memahami nilai-nilai yang terkandung didalam perilaku indivindu yang memungkinkan dalam kondisi yang tidak jelas. Dalam arti bahwa nilai dari suatu perilaku sangat sulit dipahami oleh orang lain (Kesuma, 2011:11).

Menurut Barbara A. Lewis, (2004: 6) karakter merupakan kualitas positif seperti: peduli, adil, jujur, hormat terhadap sesama dan bertanggung jawab. Sedangkan menurut megawagi karakter ini mirip dengan ahlak yang berasal dari kata Khuluk, yaitu tabiat atau kebiasaan melakukan hal-hal yang baik (Ratna Megawagi, 2005:23)

\section{c. Nilai - Nilai Karakter dalam Dunia Pendidikan}

Berikut adalah 18 Nilai dalam Pendidikan Karakter Bangsa, yang disusun oleh Pusat Kurikulum Balitbang Dikbud, Kementerian Pendidikan dan Kebudayaan. Mulai tahun ajaran 2011, seluruh tingkat pendidikan di Indonesia harus menyisipkan pendidikan berkarakter tersebut dalam pendidikan (Imron Rosyidi, 2009:18)

1. Religius. Dengan sikap dan perilaku yang patuh terhadap melaksanakan ajaran agama bagi setiap peneluknya, toleran, dan hidup rukun dengan pemeluk-pemeluk lainnya.

2. Jujur. Perilaku yang berupaya agar dirinya sebagai orang yang yang dapat dan selalu dipercaya baik dari segi perkataan, tindakan, dan pekerjaan.

3. Toleransi. Sikap dan perilaku yang cinta akan perbedaan seperti etnis, suku, pendapat, agama dan tindakan yang berbeda.

4. Disiplin. Perilaku yang menunjukkan tertip dan patuh terhadap ketentuan dan peraturan demi tercapainya sebuah keteraturan dalam aktivitas.

5. Kerja Keras. Perilaku yang menampilkan tertip dan patuh terhadap berbagai peraturan dan pekerjaan terhadap segala hal.

6. Kreatif. Berpikir untuk berkarya dengan menghasilkan sesuatu yang baru, atau hasil baru. 
7. Mandiri. Sikap dan perilaku yang tidak mudah mengharapkan belas kasih dari orang lain dalam menyelesaikan pekerjaan atau kebutuhan, tugas-tugasnya sendiri.

8. Demokratis. Cara berfikir, bersikap, dan bertindak yang menilai sama hak dan kewajiban dirinya dan orang lain.

9. Rasa Ingin Tahu. Sikap dan tindakan yang selalu berupaya untuk mengetahui lebih mendalam dan meluas dari sesuatu yang dipelajarinya, dilihat, dan didengar.

10. Semangat Kebangsaan. Cara berpikir, bertindak, dan berwawasan yang menempatkan kepentingan bangsa dan negara di atas kepentingan diri dan kelompoknya.

11. Cinta Tanah Air. Cara berpikir, bertindak, dan berwawasan yang menempatkan kepentingan bangsa dan negara di atas kepentingan diri dan kelompoknya.

12. Menghargai Prestasi. Sikap dan tindakan yang mendorong dirinya untuk menghasilkan sesuatu yang berguna bagi masyarakat, dan mengakui, serta menghormati keberhasilan orang lain.

13. Bersahabat/Komunikatif. Sikap dan tindakan yang mendorong dirinya untuk menghasilkan sesuatu yang berguna bagi masyarakat, dan mengakui, serta menghormati keberhasilan orang lain.

14. Cinta Damai. Sikap dan tindakan yang mendorong dirinya untuk menghasilkan sesuatu yang berguna bagi masyarakat, dan mengakui, serta menghormati keberhasilan orang lain.

15. Gemar Membaca Kebiasaan menyediakan waktu untuk membaca berbagai bacaan yang memberikan kebajikan bagi dirinya.

16. Peduli Lingkungan. Sikap dan tindakan yang selalu berupaya mencegah kerusakan pada lingkungan alam di sekitarnya, dan mengembangkan upaya-upaya untuk memperbaiki kerusakan alam yang sudah terjadi.

17. Peduli Sosial. Sikap dan tindakan yang selalu ingin memberi bantuan pada orang lain dan masyarakat yang membutuhkan.

Tanggung Jawab. Sikap dan perilaku seseorang untuk melaksanakan tugas dan kewajibannya, yang seharusnya dia lakukan, terhadap diri sendiri, masyarakat, lingkungan (alam, sosial dan budaya), negara dan Tuhan Yang Maha Esa.

\section{d. Proses Pembentukan Karakter}

Karakter seseorang pada dasarnya terbentuk melalui proses pembelajaran yang cukup panjang. Karakter manusia tidaklah dibawa sejak lahir, karena karakter terbentuk oleh faktor lingkungan dan juga orang yang ada sekitar lingkungan tersebut. 
Karakter terbentuk melalui berbagai proses pembelajaran yang didapatkan dari berbagai tempat seperti rumah, sekolah dan juga lingkungan tempat tinggal. Pihak yang berperan dalam pembentukan karakter seseorang antara lain keluarga, guru dan teman.

Karakter dikembangkan melalui tahap pengetahuan (knowing), pelaksanaan (acting), dan kebiasaan (habit). Karakter tidak terbatas pada pengetahuan saja. Seseorang yang memiliki pengetahuan kebaikan belum tentu mampu bertindak sesuai dengan pengetahuannya, jika tidak terlatih (menjadi kebiasaan) untuk melakukan kebaikan tersebut. Karakter juga menjangkau wilayah emosi dan kebiasaan diri. Dengan demikian diperlukan tiga komponen karakter yang baik (components of good character) yaitu moral knowing (pengetahuan tentang moral), moral feeling atau perasaan (penguatan emosi) tentang moral, dan moral action atau perbuatan bermoral. Hal ini diperlukan agar peserta didik dan atau warga sekolah lain yang terlibat dalam sistem pendidikan tersebut sekaligus dapat memahami, merasakan, menghayati, dan mengamalkan (mengerjakan) nilai-nilai kebajikan (moral).

Dimensi-dimensi yang termasuk dalam moral knowing yang akan mengisi ranah kognitif adalah kesadaran moral (moral awareness), pengetahuan tentang nilainilai moral (knowing moral values), penentuan sudut pandang (perspective taking), logika moral (moral reasoning), keberanian mengambil sikap (decision making), dan pengenalan diri (self knowledge). Moral feeling merupakan penguatan aspek emosi peserta didik untuk menjadi manusia berkarakter. Penguatan ini berkaitan dengan bentuk-bentuk sikap yang harus dirasakan oleh peserta didik, yaitu kesadaran akan jati diri (conscience), percaya diri (self esteem), kepekaan terhadap derita orang lain (emphaty), cinta kebenaran (loving the good), pengendalian diri (self control), kerendahan hati (humility). Moral action merupakan perbuatan atau tindakan moral yang merupakan hasil (outcome) dari dua komponen karakter lainnya. Untuk memahami apa yang mendorong seseorang dalam perbuatan yang baik (act morally) maka harus dilihat tiga aspek lain dari karakter yaitu kompetensi (competence), keinginan (will), dan kebiasaan (habit).

Pengembangan karakter dalam suatu sistem pendidikan adalah keterkaitan antara komponen-komponen karakter yang mengandung nilai-nilai perilaku, yang dapat dilakukan atau bertindak secara bertahap dan saling berhubungan antara pengetahuan nilai-nilai perilaku dengan sikap atau emosi yang kuat untuk 
melaksanakannya, baik terhadap Tuhan YME, dirinya, sesama, lingkungan, bangsa dan negara serta dunia internasional (lihat Gambar 1).

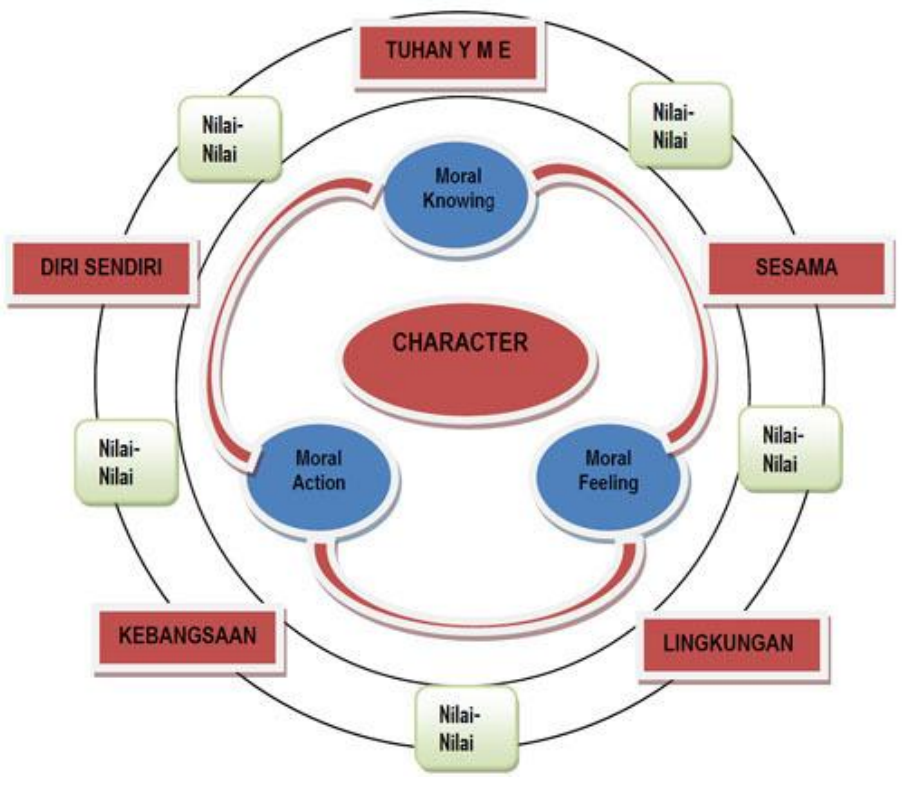

\section{Gambar 1. Keterkaitan Komponen Moral dalam Pembentukan Karakter}

\section{e. Pengertian Pendidikan Keagamaan}

Dalam peraturan pemerintah RI telah dijelaskan mengenai pengertian tentang pendidikan keagamaan yaitu "pendidikan keagamaan adalah pendidikan yang mempersiapkan peserta didik untuk dapat menjalankan peranan yang menuntut penguasaan pengetahuan tentang ajaran agama dan/atau menjadi ahli ilmu agama dan mengamalkan ajaran agamanya". (Pemerintah RI, Undang-Undang No 55 Tahun 2007 Tentang Pendidikan Agama Dan Pendidikan Keagamaan, Pasal 1 ayat 2).

Pendidikan Keagamaan dalam hal ini bermuara dalam konsep pendidikan Islam adalah memberi pendidikan manusia seutuhnya, akal dan hatinya, rohani dan jasmaninya, akhlak dan keterampilannya. Karena itu, pendidikan agama islam menyiapkan manusia untuk hidup baik dalam keadaan damai maupun perang, dan menyiapkannya untuk menghadapi masyarakat dengan segala kebaikan dan kejahatannya, manis dan pahitnya ( M. Yusuf Al-Qardhawi, 1980: 157).

Pendidikan keagamaan pada anak lebih bersifat teladan atau peragaan hidup secara riil dan anak belajar dengan cara meniru-niru, menyesuaikan dan mengintegrasikan diri dalam suatu suasana. Karena itu, latihan-latihan keagamaan dan 
pembiasaan itulah yang harus lebih ditonjolkan, misalnya latihan ibadah shalat, berdoa, membaca al-Qur'an, menghafal ayat atau surat-surat pendek, shalat berjamaah di masjid dan mushalla, pembiasaan akhlak dan budi pekerti baik, berpuasa dan sebagainya (Muhaimin, 2001: 294). Firman Allah dalam Al Qur'an surat Al-Qalam: 4

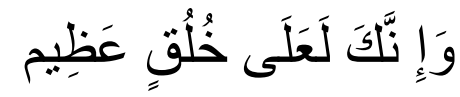

Artinya : Dan sesungguhnya kamu benar-benar berahlaq yang agung. (QS. AlQalam: 4)

Kandungan yang mendalam dalam melaksanakan pendidikan keagamaan adalah agar seseorang beriman dan beribadah sesuai dengan agama Islam. Pendidikan keagamaan pada tahap akhir adalah sebuah proses pencapaian yang membentuk kepribadian seseorang setelah melalui tahap mengetahui, berbuat dan mengamalkannya (Haidar Putra Daulay, 2009: 35). Kepribadian keagamaan yang dimaksudkan adalah kepribadian yang sesuai dengan ajaran agama Islam secara sempurna.

Pendidikan keagamaan pada anak lebih bersifat teladan atau peragaan hidup secara riil dan anak belajar dengan cara meniru-niru, menyesuaikan dan mengintegrasikan diri dalam suatu suasana. Karena itu, latihan-latihan keagamaan dan pembiasaan itulah yang harus lebih ditonjolkan, misalnya latihan ibadah shalat, berdoa, membaca al-Qur'an, menghafal ayat atau surat-surat pendek, shalat berjamaah di masjid dan mushalla, pembiasaan akhlak dan budi pekerti baik, berpuasa dan sebagainya. Agama merupakan hal yang sangat penting untuk diajarkan sedini mungkin, proses kepada peserta didik harus diajarkan sejak masa kanak-kanak, sebab pertumbuhan keagamaan masa kanak-kanak adalah mutu pengalaman yang berlangsung lama dengan orang-orang dewasa yang berarti penting bagi mereka. pengalaman awal dan emosional dengan orang tua dan orang dewasa yang berarti merupakan dasar pembangunan keagamaan dimasa mendatang. mutu afektif hubungan anak dan orang tua merupakan bobot lebih dan dasar utama sebelum pengajaran secara sadar dan kognitif yang diberikan setelahnya

\section{METODOLOGI PENELITIAN}

Jenis penelitian yang digunakan adalah penelitian lapangan (field research) yaitu jenis penelitian yang berusaha menghimpun data penelitian secara langsung di lapangan, seperti di lingkungan masyarakat, lembaga-lembaga dan 
organisasi kemasyarakatan dan lembaga pendidikan formal maupun non formal. (Sarjono dkk, 2008:21).

Penelitian ini termasuk penelitian kualitatif deskriptif, penyajian data hasil penelitiannya dipaparkan dalam bentuk uraian deskripsi.

\section{HASIL KAJIAN DAN PEMBAHASAN}

\section{a. Upaya pembentukan karakter pada anak melalui pendidikan keagamaan di MI Salafiyah 02 Tasikmadu}

Hasil observasi dan wawancara yang peneliti lakukan adalah sebagai berikut :

1. Hasil observasi

Observasi dilakukan ketika kegiatan pendidikan keagamaan dilaksanakan. Berikut hasil observasi ketika kegiatan rutin sholat dhuha, istighosah dan Maulud Nabi Muhammad SAW:

- Kegiatan sholat dhuha

Ketika anak - anak mendengar bel, yang awalnya bermalas - malasan menuju musolla sekolah, kini dengan pembentukan karakter anak - anak mulai sadar bahwa kegiatan sholat dhuha sangat bermanfaat untuk meningkatkan iman dan takwa. Berikut ini petikan catatan lapangan yang menggambarkan suasana tersebut:

“Anak - anak mulai berbondong - bong menuju musolla ketika mendengar bel. Anak perempuan meletakan mukena didalam musolla. Selain itu anak lakilaki sibuk antri untuk berwudlu. Anak laki yang sudah berwudhu segera adzan kemudian merapikan shaf shalat. Shaf paling depan diisi oleh anak laki - laki dan dibelakangnya di susul dengan anak perempuan."

Demikian kegiatan rutin yang dilaksanakan di MI Salafiyah 02 Tasikmadu yang bisa menyadarkan anak - anak bahwa dengan kegiatan keagamaan seperti ini sangat bermanfaat bagi mereka.

- Kegiatan istighosah

Istighosah dilaksanakan setiap hari Jum'at Wage. Yang tidak hanya diikuti oleh anak kelas V melainkan seluruh anak yang ada di MI Salafiyah 02 Tasikmadu. Berikut petikan catatan lapangan yang menggambarkan suasana tersebut:

"Anak - anak yang mulanya berangkat agak siang, kini setelah diadakan istighosah pagi akan berangkat pagi. Setiap hari Jum'at jam 06.00 pagi anak 
- anak sudah mulai berkumpul disekolah untuk melaksanakan istighosah. Anak yang besar mulai menata tempat duduk dengan meletakan tikar. Tempat duduk laki - laki dan perempuan dipisah. Anak laki - laki berada didepan sedangkan anak perempuan berada dibelakang anak laki - laki. Selama kegiatan anak - anak diberi kertas berisi bacaan istighosah. Pertama yang dibaca adalah surat Yasin kemudian bacaan Istighosan dilanjutkan dengan bacaan tahlil dan diakhiri dengan do'a. Setelah kegiatan selesai anak - anak kembali ke kelas dengan tertib."

Itulah cuplikan kegiatan keagaamaan yang berupa istighosah yang dilaksanakan setiap hari Jum'at Wage yang dapat membentuk karakter anak melalui kegiatan keagamaan.

- Kegiatan Maulid Nabi Muhammad SAW

Kegiatan Maulid Nabi SAW memang tidak menjadi kegiatan rutin sehari hari, namun kegiatan tersebut selalu dilaksanakan setiap setahun sekali dalam bulan Maulud. Kegiatan ini bertujuan agar anak - anak tidak lupa dengan kelahiran Nabi Muhammad SAW. Karena seiring berkembangnya zaman yang semakin modern ini. Berikut petikan catatan lapangan yang menggambarkan suasana tersebut:

"Sebelum kegiatan berlangsung anak - anak sudah diberi pengumuman. Pagi - pagi anak mulai berangkat dengan pakaian yang rapi yaitu tidak seperti biasa yang mengenakan baju seragam melainkan memakai busana muslim. Anak laki - laki banyak yang mengenakan sarung dengan baju koko dan memakai peci, sedangkan anak perempuan memakai rok dan baju busana dibalut dengan kerudung yang sangat cantik. Setiap anak membawa snack (jajan) dan dikumpulkan menjadi satu di ruang guru. Guru mulai membungkus jajan yang dibawa anak - anak. Kemudian anak - anak mulai berkumpul di kelas untuk melaksakan acara Maulid. Kegiatan dibuka oleh pembawa acara dengan bacaan basmalah, kemudian bacaan maulid lalu diteruskan dengan mauidhoh hasanah (pengajian) dan diakhiri dengan do 'a.'

Demikian kegiatan tahunan yang dilaksanakan dalam memperingati hari Maulid Nabi Muhammad SAW di MI Salafiyah 02 Tasikmadu yang berjalan dengan lancar dengan pengajian yang bisa mengingatkan kepada anak - anak bahwasanya kita haris selalu membaca sholawat nabi agar kelak kita mendapat syafaat dari Nabi Muhammad SAW. 
Dari hasil observasi dapat kita lihat bukti bahwasanya kegiatan pendidikan keagamaan dapat membentuk karakter anak dengan tabel berikut:

Tabel 1 kenampakan kegiatan pendidikan keagamaan untuk membentuk karakter

\begin{tabular}{|c|c|c|c|c|}
\hline No. & Nama & Karakter & Terlihat & $\begin{array}{l}\text { Tidak } \\
\text { terlihat }\end{array}$ \\
\hline 1. & $\begin{array}{l}\text { Achmad Bani Adam Nur } \\
\text { Afwan }\end{array}$ & \multirow{15}{*}{$\begin{array}{l}\text { 1. Religius } \\
\text { 2. Jujur } \\
\text { 3. Toleransi } \\
\text { 4. Disiplin } \\
\text { 5. Kerja keras } \\
\text { 6. Kreatif } \\
\text { 7. Mandiri } \\
\text { 8. Demokratis } \\
\text { 9. Rasa ingin tahu } \\
\text { 10. Semangat } \\
\text { kebangsaan } \\
\text { 11. Cinta tanah air } \\
\text { 12. Menghargai } \\
\text { prestasi } \\
\text { 13. Bersahabat / } \\
\text { Komunikatif } \\
\text { 14. Peduli } \\
\text { (Lingkungan dan } \\
\text { sosial) } \\
\text { 15. Tanggung jawab }\end{array}$} & $\checkmark$ & \\
\hline 2. & $\begin{array}{ll}\text { Afro' } & \text { Kisbiyyatul } \\
\text { Farodis } & \end{array}$ & & $\sqrt{ }$ & \\
\hline 3. & Alfa Naufal Musthofa & & $\checkmark$ & \\
\hline 4. & Ashabul Khafi & & $\sqrt{ }$ & \\
\hline 5. & Dini Lydia Ningsih & & & $\checkmark$ \\
\hline 6. & Hani Safitri & & $\checkmark$ & \\
\hline 7. & Istiya Desi Nur Cahyani & & $\checkmark$ & \\
\hline 8. & Mia Nurjanah & & $\checkmark$ & \\
\hline 9. & Muhammad Mustaqim & & $\checkmark$ & \\
\hline 10. & Ninda Silviana Sholihah, & & $\checkmark$ & \\
\hline 11. & Siti Himatus Sholihah & & $\checkmark$ & \\
\hline 12. & Siti Maghfiroh & & $\checkmark$ & \\
\hline 13. & Naila Aska Maulana & & & $\checkmark$ \\
\hline 14. & $\begin{array}{l}\text { Iffatuddiyyanah } \quad \mathrm{Al} \quad- \\
\text { Azka }\end{array}$ & & $\checkmark$ & \\
\hline 15. & Ardeni Bariq Azhari & & $\checkmark$ & \\
\hline
\end{tabular}


Dari tabel diatas dapat ditarik kesimpulan bahwasanya 90\% anak - anak mulai bersemangat terhadap kegiatan keagamaan dengan karakter yang diselipkan dalam pendidikan keagamaan yang dilaksanakan di MI Salafiyah 02 Tasikmadu.

2. Hasil wawancara pada siswa

Wawancara dilakukan pada anak kelas V sebagai berikut:

1) Apakah menurut anak - anak pendidikan keagamaan itu penting?

Tabel 2 jawaban wawancara soal pertama pada Siswa

\begin{tabular}{|c|c|c|}
\hline No. & Nama Panggilan & Jawaban \\
\hline 1. & Affan & Penting \\
\hline 2. & Odis & Penting \\
\hline 3. & Naufal & Penting \\
\hline 4. & Khafi & Tidak tahu \\
\hline 5. & Dini & Penting \\
\hline 6. & Hani & Penting \\
\hline 7. & Desi & Penting \\
\hline 8. & Janah & Penting \\
\hline 9. & Taqim & Penting \\
\hline 10. & Ninda & Penting \\
\hline 11. & Hima & Penting \\
\hline 12. & Firoh & Penting \\
\hline 13. & Naila & Tidak tahu \\
\hline 14. & Dina & Penting \\
\hline 15. & Ardan & Penting \\
\hline
\end{tabular}

Penting : $90 \%$

Tidak tahu : $10 \%$ 
Dari jawaban anak - anak yang masih belum tahu bahwasanya pendidikan keagamaan itu penting sebanyak $10 \%$ sedangkan yang merasa penting adalah $90 \%$. Maka dari hasil yang diperoleh peneliti dapat disimpulkan bahwa dengan dilaksanakanya kegiatan pendidikan keagamaan itu penting untuk membentuk karakter anak.

3) Apakah kegiatan rutin keagamaan yang ada disekolah kamu terapkan dirumah?

Tabel 3 Jawaban wawancara soal kedua pada Siswa

\begin{tabular}{|c|c|c|}
\hline No. & Nama Panggilan & Jawaban \\
\hline 1. & Affan & Iya \\
\hline 2. & Odis & Iya \\
\hline 3. & Naufal & Iya \\
\hline 4. & Khafi & Kadang - kadang \\
\hline 5. & Dini & Kadang - kadang \\
\hline 6. & Hani & Iya \\
\hline 7. & Desi & Iya \\
\hline 8. & Janah & Iya \\
\hline 9. & Taqim & Iya \\
\hline 10. & Ninda & Iya \\
\hline 11. & Hima & Iya \\
\hline 12. & Firoh & Kadang - kadang \\
\hline 13. & Naila & Kadang - kadang \\
\hline 14. & Dina & Iya \\
\hline 15. & Ardan & Kadang - kadang \\
\hline
\end{tabular}

$\begin{array}{ll}\text { Diterapkan } & : 65 \% \\ \text { Kadang - kadang } & : 35 \%\end{array}$


Dari jawaban anak-anak yang diperoleh peneliti dari 15 anak yang diterapkan adalah $65 \%$, dan yang kadang - kadang diterapkan 35\%. Maka dapat disimpulkan bahwa kegiatan pendidikan keagamaan telah tertanam dalam diri anak, terbukti $65 \%$ anak - anak menerapkan dirumah.

4) Apakah kegiatan pendidikan keagamaan ini menjadi beban bagi anak - anak ?

Tabel 4 Jawaban wawancara soal ketiga pada Siswa

\begin{tabular}{|l|l|l|}
\hline No. & \multicolumn{1}{|c|}{ Nama Panggilan } & \multicolumn{1}{|c|}{ Jawaban } \\
\hline 1. & Affan & Tidak \\
\hline 2. & Odis & Tidak \\
\hline 3. & Naufal & Tidak \\
\hline 4. & Khafi & Tidak \\
\hline 5. & Dini & Tidak \\
\hline 6. & Hani & Tidak \\
\hline 7. & Desi & Tidak \\
\hline 8. & Janah & Tidak \\
\hline 9. & Taqim & Tidak \\
\hline 10. & Ninda & Tidak \\
\hline 11. & Hima & Tidak \\
\hline 12. & Firoh & Tidak \\
\hline 13. & Naila & Tina \\
\hline 15. & Ardan & \\
\hline
\end{tabular}

Tidak terbebani $: 100 \%$

Terbebani $: 0 \%$ 
Dari jawaban anak - anak yang diperoleh $100 \%$ anak - anak tidak merasa terbebani dengan kegiatan pendidikan keagamaan yang diterapkan disekolah yang akan membentuk karakter anak menjadi anak yang sholeh.

\section{b. Efektivitas Pembentukan Karakter pada Anak melalui Pendidikan Keagamaan di MI Salafiyah 02 Tasikmadu}

Dari hasil observasi dan wawancara pada anak-anak di MI Salafiyah 02 Tasikmadu, dapat dikatakan bahwa dalam pendidikan keagamaan sangat penting untuk membentuk karakter anak menjadi yang lebih sholeh dan sholehah. Membentuk karakter anak memerlukan proses waktu yang cukup, berperilaku yang baik tentu banyak sekali tantangan baik pada anak itu sendiri maupun guru yang mendidik, kadang-kadang sudah dapat dikatakan berubah, namun dengan pergaulannya, sifat tersebut berubah lagi. Setelah dibimbing dan diawasi oleh guru melalui pendidikan keagamaan anak-anak mulai berubah dan mengerti akan pentingnya perilaku yang baik. Pendidikan yang didapat dari sekolah melalui pendidikan keagamaan mulai diterapkan sedikit demi sedikit dan bisa diterapkan. Terbukti bahwa banyak anak-anak yang menerapkan dirumah. Selain dirumah, perilaku anak-anak sangat kelihatan ketika berada disekolah. Awalnya sebelum dilakukan penelitian, karakter anak belum kelihatan namun setelah dilakukan penelitian oleh peneliti karakter anak mulai kelihatan karena adanya pendidikan keagamaan yang diterapkan dalam penelitian ini.

\section{c. Faktor Penghambat dan Pendukung dalam Pembentukan Karakter pada Anak melalui Pendidikan Keagamaan di MI Salafiyah 02 Tasikmadu}

Dalam membentuk karakter anak melalui pendidikan keagamaan itu tidak mudah dan memerlukan waktu yang cukup serta proses yang lama karena ada faktor penghambat dan faktor pendukung dalam penelitian ini. Faktor penghambat dari penelitian ini adalah tempat melaksanakan kegiatan dalam pembentukan karakter di lembaga ini untuk fasilitas sarananya kurang luas dan belum bisa menampung anak-anak untuk melaksanakan kegiatan, khususnya melaksanakan kegiatan sholat dhuha dan sholat dhuhur berjamaah, sehingga anak-anak masih bergantian dengan kelas lain, kurangnya antusias anak terhadap kegiatan keagamaan, selain itu masih ada anak yang suka bergurau saat kegiatan berlangsung. Faktor pendukung dalam pembentukan kegiatan pendidikan keagamaan adalah guru-guru yang ada di MI Salafiyah 02 Tasikmadu selalu mengikuti kegiatan yang dilakukan, sehingga mendapatkan respon positif dari 
anak-anak. Jadi anak dalam melaksanakan kegiatan keagamaan merasa terdorong dan semangat untuk mengikuti serta mulai antusias dengan kegiatan pendidikan keagamaan selalu mengawali ketika kegiatan berlangsung.

\section{E. KESIMPULAN DAN SARAN}

Berdasarkan pembahasan dalam penelitian membentuk karakter anak kelas V melalui pendidikan keagamaan di MI Salafiyah 02 Tasikmadu dapat ditarik kesimpulan sebagai berikut:

1. Upaya untuk membentuk karakter anak melalui pendidikan keagamaan dengan cara mengajak anak -anak untuk melakukan kegiatan keagamaan. Misalnya sholat dhuha bersama, istighosah do'a sebelum dan sesudah belajar dll. Itu semua merupakan bagian dari upaya yang dilakukan peneliti untuk membiasakan anak-anak supaya memiliki kesadaran untuk melakukan kegiatan keagamaan. Dengan membentuk karakter anak melalui pendidikan keagamaan, anak-anak mulai memahami pentingnya pendidikan keagamaan. Karena pendidikan keagamaan tidak hanya diterapkan disekolah namun bisa diterapkan dimana saja contohnya dirumah atau dilingkungan sekitar.

2. Efektifitas pendidikan keagamaan dalam membentuk karakter di MI Salafiyah mulai terlihat. Anak-anak yang awalnya males melakukan kegiatan pendidikan keagamaan kini mulai aktif dengan dibarengi pembentukan karakter yang dilakukan rutin setiap hari. Pendidikan keagamaan sangat efektif dalam membentuk karakter anak yang mulai luntur dengan perkembangan zaman. Dengan diadakan penelitian ini, di MI Salafiyah 02 Tasikmadu mulai terlihat karakter itu muncul dengan berbagai kegiatan pendidikan keagamaan.

Dalam membentuk karakter anak melalui pendidikan akan mudah bila anak-anak selalu aktif dalam kegiatan tersebut. Meskipun ada faktor penghambat maupun pendukung itu tidak akan menjadi halangan bagi peneliti untuk tetap melalukan penelitian. Faktor penghambat dari penelitian ini adalah tempat yang kurang luas, karena anak-anak masih bergantian dengan kelas lain, kurangnya antusias anak terhadap kegiatan keagamaan, selain itu masih ada anak yang suka bergurau saat kegiatan berlangsung. Faktor pendukung dalam pembentukan kegiatan pendidikan adalah guru-guru yang ada di MI Salafiyah 02 Tasikmadu selalu mengikuti kegiatan yang dilakukan, anak-anak yang mulai antusias dengan kegiatan pendidikan keagamaan selalu mengawali ketika kegiatan berlangsung. 


\section{DAFTAR PUSTAKA}

Depag. RI. 2001. Kendali Mutu Pendidikan Agama Islam. Jakarta : Direktorat Djamarah. 2005. Keterampilan Penguatan, (Online),

(http://djamarahtkipmpl.wordpress.com, diakses tanggal 25 Desember 2017).

ER, Umar.2011. Panduan Sholat \& Do’a, Surabaya: Lingkar Media

Margono, 1997, Metodologi penelitian pendidikan, Jakarta : PT Rineka Cipta

Mudyahardjo,Redja.2006, Filsafat Ilmu Pendidikan,Suatu Pengantar, PT.Remaja Rosdakarya, Bandung

Rosyidi, Imron. 2009, Pendidikan Berparadigma Inklusif, Malang:UIN-Malang Press

Surya, Yohanes. 2009. Keterampilan Memberi Penguatan, (Online), (http://semangatgasing.blogspot.com, diakses tanggal 17 Desember 2017).

Syaiful, Sagala. 2006. Konsep dan Makna Pembelajaran. Bandung: alfabeta

Tafsir, Ahmad. 2006. Filsafat Pendidikan Islami. Bandung: PT. Remaja Rosdakarya.

Usman, Husaini, 2006. Manajemen, Teori, Praktik, dan Riset Pendidikan. Jakarta: Bumi Aksara.

Wahyudin, dkk. 2006. Pengantar Pendidikan, Universitas Terbuka, Jakarta

Wartono. 2003. Keterampilan Dasar Mengajar. Malang: Universitas Kanjuruhan. 